\title{
THE DEATH OF DUMUZI: A NEW SUMERIAN VERSION
}

\section{By SAMUEL NOAH KRAMER}

As of today there are several variant versions of the myth relating to the death of Dumuzi, the more important of which are: "Inanna's Descent to the Nether World", "Dumuzi's Dream"," "Dumuzi and the galla."3 The text here edited, inscribed on a hitherto unpublished tablet, BM 100046, consists of an account of Dumuzi's death that parallels to some extent the hitherto known versions, but includes a number of rather unusual themes and intriguing motifs not found in any of them. ${ }^{4}$ It is a pleasure and a privilege to dedicate this study to Oliver Gurney with whom I collaborated in preparing a volume of Sumerian literary texts in the Ashmolean Museum (OECT V), and who moreover published in the year 1962 an exemplary summary of what was then known about Dumuzi and his tragic death. ${ }^{5}$

The new version of the death of Dumuzi is composed of four sections. The first (lines 1-19) is in the form of an Emesal address by some individual to Dumuzi consisting of such exclamatory questions as: why does he walk about with covered head while his ewes and their lambs, his she-goats and their kids, as well as his holy little donkey-mares have been seized and carried off, and his holy churn lies shattered; why do his large kids lie prostrate in the sheep-pen and why do his small kids shed bitter tears in the feeding-pen; why do the motherless lambs cry bitterly as they wander aimlessly about, while his weeping little sister utters supplications in their midst. His dog, continues the address, is uttering bitter cries in the desolate steppe; his spouse, holy Inanna, is weeping bitterly in the Eanna; his noble sister Geštinanna is rending her sinews and plucking out her hair at the gate of Lugalbanda and the boulevard of Ninsun. ${ }^{6}$

In the second section, written in Emegir (lines 20-43), Dumuzi is depicted weeping "at the meaning of the fate decreed (for him)." "7 and complaining that he had been singled out for misfortune after he had walked among men; ${ }^{8}$ that all the calamities enumerated in the

${ }^{1}$ Cf. now W. R. Sladek's very useful dissertation based almost entirely on my earlier researches and publications. Note, too, that $U E T$ VI No. 11 is a variant version of the second half of the myth that seems to end in medias res, and was probably continued on another tablet.

${ }^{2}$ Cf. now B. Alster's important monograph, Dumuzi's Dream, based largely on contributions by Falkenstein, Jacobsen, Van Dijk, and Kramer.

3 The text is still untranslated in large part; for partial translations cf. Kramer, The Sacred Marriage Rite, pp. 127-130; Jacobsen, Treasures of Darkness, pp. 49-52; Alster, Dumuzi's Dream, p. 116. Note especially that the crucial concluding passage of the composition has been misunderstood to some extent in both The Sacred Marriage Rite and Treasures of Darkness (cf. my forthcoming study in the Proceedings of the American Philosophical Society).

4 Though the text is well preserved and almost complete, its translation and interpretation are difficult and problematic, and the present study is a pioneering effort to be corrected and amended by scholars with deeper linguistic and philological insights.

s"Tammuz Reconsidered; Some Recent Developments" (Journal of Semitic Studies 7: 147-160).

- The fact that the poet envisaged Geštinanna as weeping for Dumuzi in localities named after Lugalbanda and Ninsun, localities which may have existed only in his imagination, indicates that the myth was composed during the Third Dynasty of Ur, when these two deities were deemed to be the parents of the king who was Dumuzi incarnate.

7 That is, ša-nam-tar-ra-ka which may of course also be rendered "in the midst of the fate decreeing". In any case, it is to be noted that the "fate decreeing" motif appears rather abruptly and unexpectedly. It may be of course that Dumuzi's fate is adumbrated and foreshadowed in the address to Dumuzi that constitutes the first section of the composition, but it is also possible that our text is part of a Dumuzi myth of some length inscribed on more than one tablet.

${ }^{8}$ The significance of this statement, assuming the rendering is correct, is not clear; on the surface it seems to imply that Dumuzi was a god who for some unstated reason had decided to mingle with mortal men. In "Dumuzi's Dream" on the other hand, Dumuzi claims that he is the husband of a goddess (line 206), and the implication is that he was a mortal who became a god as a result of his marriage to Inanna. 
speech addressed to him had indeed come upon him; that his spouse Inanna was indeed weeping for him in the Eanna, and that his sister was indeed lacerating her body racked with agony. Moreover, continues Dumuzi, he actually sees himself sliding into the grave that stands before him "like a big door," and from which he cannot rise while the cruel rain-pouring wind and the tempest maim and ravage him. ${ }^{9}$

The third section, written mainly in Emesal, consists of two parts. The first (lines 44-50), describes Dumuzi's seizure by the galla:10 they surround him, torment him with thirst, hold on to his side, bind his hands that had been soiled in dung, seize him by his thighs as he is proudly seated, remove his crushed cover from his holy churn. The second part of the section (lines 51-59) begins with two lines that provide the reason for Dumuzi's death: his spouse Inanna had died and he was to take her place in the Nether World. Then follow seven lines, each ending with the refrain giš-búr-ra ba-an-díb "'he was held fast by the gišbur-trap"), that depict the wretchedness of the Nether World:11 there was food there but it was not edible; there was water there but it was not drinkable; it was a place where Namtar dwelt, where arts and crafts were unknown, where lips were covered with blood.

The fourth section, also written in the Emesal, ${ }^{12}$ introduces a number of themes and motifs relating to sorcery, witcheraft, and burial rites, that are altogether new to the Dumuzi myth as known hitherto. ${ }^{13}$ The section consists of two parts. In the first (lines 60-74) we are introduced to seven arali-sorcerers who seem to be able to work magic with the huluppu-tree, and who are expert in the witchcraft relating to the gu-bad-DU $U^{14}$ which they stretch out in heaven and on earth, and within which the shepherd brings his sheep secretly. In the second part of the section (lines 75-87), we find a witchcraft-practising shepherd who had dug a hole in the ground and had broken a jug of wine in the edin which was being churned like milk; also a young maid who "made an ornament" there, and a young bride who brought bitumen there; the mes-tree brought something (the relevant signs are destroyed) there, and the asal-tree whose fruit had perished stretched its shade there. All this seems to be preparatory to the burial of the shepherd with his dog which is probably depicted in the last four lines of the composition that read:

At the side of the corpse the dog lay,

In his hut the raven [dwelt],

The dog ate by (his) side, [lay] at his feet,

The raven ate by (his) side, ascended to heaven.

${ }^{9}$ Lines 40-43 certainly seem to say that Dumuzi had some foresight and foretaste of his death and burial, but there is nothing in the text to indicate how this came about.

${ }_{10}$ The appearance of the galla on the scene is rather abrupt and unanticipated; there is nothing in the preceding passage to prepare us for their advent, and this again may indicate that our text consists of the conclusion of a myth inscribed on more than one tablet (cf. note 7).

${ }^{11}$ Actually it is not the Nether World as a whole that seems to be depicted, but only the ès-lam of Ereškigal. The meaning of éšlam is quite uncertain, perhaps it means "the lam-shrine," lam being a rare word for "Nether World" (cf. CAD sub lammu, and note that the lam of dmes-lam-ta-è-a may also refer to the Nether World).

${ }^{12}$ Cf. $e$-zé (for $u d u$ ) in line 73, me-ri (for gìr) in lines 74 and 86, and mu-tin (for geštin) in line 76 but note the Emegir lú-sipad in line 75 (and perhaps sipad in line 72 ).

${ }_{13}$ Unfortunately as the commentary to this section notes, much of it is incomprehensible and the summary sketch of its contents here presented is far from assured.

14 The literal rendering of gu-bad-DU may of course be "the separating thread" or "the distant thread," but neither meaning helps to clarify the witchcraft involved. 


\section{Transliteration ${ }^{15}$}

1. [e-na ba-LU]-LU e-ne ba-LU-LU sag túg a-[na-aš bí-in-dul]

2. [za-e sipad-me-en] e-ne ba-[LU-LU]

3. [u $u_{8}$-zu ì-díb sila ${ }_{4}-{ }^{-z u}$ ì-rig $\left.{ }_{7}\right]$ e-ne ba-LU-LU

4. [ùz-zu ì-díb máš-zu ì-rig ] e-ne ba-LU-LU

5. [eme $e_{\mathbf{x}}$-tur-kù-zu i-im-da-díb] e-ne ba-LU-LU

6. [dukšakìr-kù-zu líl-e ì]-sìg-ge sag túg a-na-aš bí-in-dul

7. máš-gal-gal-[zu é]-e-zé-ka gú ki a-na-aš ì-ma-al

8. máš-tur-tur-zu é-ubara ${ }^{16}-k a$ ír-gig i-[še $\left.{ }_{8}\right]$

9. sila ${ }_{4}$-ama-nu-tuku-zu úr-bal-bàd-da-ka gù gig-bi im-[me]

10. nin $_{9}$-bàn-da-ír-ra-tuku-a-zu šà-bi šà-ne-ša ${ }_{4}$ a-na-aš ba-gá-gá

11. ur-zu edin-líl-lá gù gig-bi im-me

12. nitalam-zu kù-ga-ša-an-an-na-ke

13. é-an-ta-ki-a-gub-ba-na ír-gig i-šs $e_{8}$-še

14. nin $_{9}$-e-zu d mu-tin-an-na-ke ${ }_{4}$

15. ká-ù-mu-un-bàn-da-ke ${ }_{4}$

16. sila-da-ma-al-la-ga-ša-an-sun-na-ke ${ }_{4}$

17. sa-ì-sur-ra-ni im-sur-re síg-ni im-zé-e

18. sa-ì-bu-ra-ni im-bu-re síg-ni im-zé-e

19. síg-ni ú-šu-mu-búr šu mu-un-dúb-dúb-bé

20. guruš-e šà-nam-tar-ra-ka ír im-ma-ni-in-pàd

21. dumu-zi-dè šà-nam-tar-ra-ka ír im-ma-ni-in-pàd

22. mà-e sipad-me-en lú-da ba-an-da-gen ${ }^{17}$-ne-ta dili a-na mu-un-ag

23. $u_{8}-m u$ hé-díb sila $a_{4}-m u$ hé-rig ${ }_{7}$ dili a-na mu-un-a $[\mathrm{g}]$

24. ùz-mu hué-díb máš-mu hé-rig dili a-ma mu-un-a[g]

25. eme $_{\mathbf{x}}$-tur-kù-mu hé-im-da-díb dili a-na mu-un-[ag]

26. dukšakìr-kù-mu líl-e ḩè-sìg-ge dili a-na mu-un-[ag]

27. máš-gal-gal-mu é-udu-ka gú ki huu-mu-ni-[gál]

28. máš-tur-tur-mu é-ubur-ra ír-gig hé-še $e_{8}\left[\mathrm{~s}_{8}\right]$

29. sila ${ }_{4}$-ama-nu-tuku-mu úr-bal-bàd-da-ka gù gig-bi hn[e-im-me]

30. $\operatorname{nin}_{9}$-bàn-da-ír-re-tuku-a-mu šà-bi šà-ne-ša ${ }_{4}$ hé-en-g[á-gá]

31. ur-mu edin-líl-la gù gig-bi hé-im-[me]

32. nitalam-mu kù-dinanna-ke

33. é-an-ta-ki-a-gub-ba-na ír-gig hé-še $e_{8}-\mathrm{s}^{-}\left[\mathrm{e}_{8}\right]$

34. nin $_{9}$-e-mu dgeštín-an-na-ke 4

35. ká-dlugal-bàn-da-ke $e_{4}$

36. sila-dagal-la-dnin-sun-na-ke ${ }_{4}$

37. sa-ni hée-sur-re síg-ni ḩe-im-zé-e

38. sa-níg-bu-ra-ni hé-sur-re síg-ni hé-im-zé-e

39. síg-ni numùn-búr-gim šu hée-im-dùb-dùb-b[é]

40. kur-ki-in-dar-ra-mà gìr-mà ba-an-zé-ir $u_{5}$ nu-mu-un-da- $\left[\mathrm{e}_{11}\right]$

41. unu-gal ig-gal-àm igi-mà ba-an-gub ${ }^{18} \mathrm{ur}_{5}$ nu-mu-un-da-[e $\left[\mathrm{e}_{11}\right]$

42. im-huul-šèg-gá me-ri-mà ba-an-zé-ir $u_{5} n u-m u-u n-d a-\left[e_{11}\right]$

43. im-ul $_{6}$-lu bal(!?)-ri-a im-ma-da- $\operatorname{lah}_{4}{ }^{19} \mathrm{ur}_{5}$ nu-mu-un-da- $e_{11}$ signs.

${ }^{15}$ In the transliteration, three dots stand for two missing signs, four dots for three or more missing

16 The sign is glossed $u-b u-r a$.

17 The sign $D U$ (read gen) is glossed by the sign $M I$.

18 The sign $D U$ (read $g u b$ ) is glossed by the sign $G U$.

${ }^{10}$ Between and under $l a h_{4}$ and $u r_{5}$ is an illegible gloss (perhaps $l a-a h-?$ ). 
44. gal[la]-gu-la ba-nigin-ne-eš a-nigín-na ba-an-ni- $\left\langle\mathrm{du}_{8}\right\rangle$-us

45. [galla-tur] ba-an-nigin-ne-eš a-nigín-na ba-an-ni- $\left\langle\mathrm{du}_{8}\right\rangle-$-us

46. .... ba-an- ....

47. galla gi-NIGír-šukur-nu-me-a [zag-ga-na ba-an-díb-bé-eš]

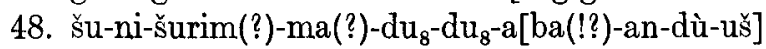

49. mah̆-a-dúr-a ba-gar-ra-àm[haš ${ }_{4}^{-a-n a ~ i-i m-d i ́ b-b e ́-e s ̌] ~}$

50. đuk-šakír-kù-ga tư-pad-pad-da-ni [ba-ra-bad-du-ušs]

51. [u ${ }_{4}$-bi-a ga-ša-an-e nu-un-ti kur-[nu-gi ${ }_{4}-a$-šè] ki-bi-[gar-na mu-un-si]

52. dam-ušum-gal-an-na-ka mu-un-ti ki-bi-gar-na mu-un-[si]

53. ddumu-zi-dè èš-lam-šè giš-búr-ra ba-an-d[díb]

54. èš-lam-šè ga-ša-an-ki-gal-la-a-šè gišs-búr-ra ba-an-[díb]

55. ú-bi ì-ma-al nu-kú-ù-dè giš-búr-ra [ba-an-díb]

56. a-bi ì-ma-al nu-nag-nag-dè gis-búr-ra [ba-an-díb]

57. ki-nam-tar-ra-durun-na-šè gišs-bur-ra [ba-an-díb]

58. nam-galam-ma ba-da-ab-ku ${ }_{6}$-lam-ma-šè giš-búr-ra [ba-an-díb]

59. šu-um-du-um-urí-na-šú-a-šè giš-bur-[ra ba-an-díb]

60. $u_{4}$-[bi]-a imin hé-na-me-eš imin hée-na-[me-es]

61. [e-ne-ne]ušs-zu-a-[ra]-li imin hé-na-[me-eš]

62. [ušx-zu]-a-ra-li hée-en-na-me-eš imin-na h̆[é-en-na-me-eš]

63. ....-kar(?) sa-àm-me šu gišha-lu-ub ${ }_{4}$-a [g-me-eš $]$

64. ? ?-?-sír-re-me-eš gıšh̆ha-lu-ub $b_{4}$-ag-me-eš imin háé-na-[me-eš]

65. šeš-nu-zu nin ${ }_{9}$-nu-zu ad-gal-u $u_{4}$-gi $i_{6}$-ga

66. e-ne-ne-ne an-na uš $x_{\mathbf{x}}$ mu-un-zu kj-a ušx mu-un-[zu]

67. an-na gu-bad-Du mu-un-na-lá-e-ne

68. ?-?-?-an-na im-mi-in-bal-e-ne

69. ki-a gu-bad-Du mu-un-na lá-e-ne

70. ?-?-ki-a im-mi-in-gi $4_{4}-\mathrm{gi}_{4}$-ne

71. más-ùz-da $\mathrm{u}_{8}$-gim dúr-ru-na bí-in-?-?

72. sipad(?)-dè ḩé-me-LU hée-me-LU zi-zi-dè(?)

73. gu-bad-DU-a na-me nu-un-zu e-zé-ni ba-ni-i[in-ku $\left.{ }_{4}\right]$

74. ki-tuš-a-ni bala nu-un-zu me-ri-ni za-ra-RI- . . .

75. lú-sipad-dè uš x-dug $_{4}$-dug ${ }_{4}$ ki-a ba-e-dar

76. edin-na duk-mu-tin-na ba-e-gaz edin ga-gim ì-hur

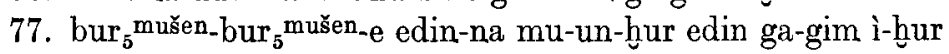

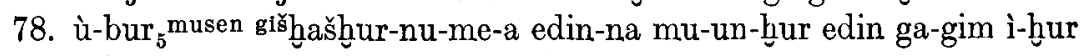

79. ù-ki-sikil-tur-re suh. ${ }^{20}$ kèš ba-ni-in-ag

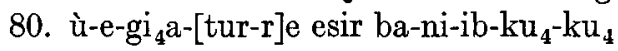

81. "glš meš-gi-bala $\ldots$ ba-ni-ib-ku ${ }_{4}-\mathrm{ku}_{4}$

82. gišasal il-lu-ur-bi ba-ab-gul-la gizzu-bi ba-ni-ib-[lá]

83. ? ? ?-gim $\mathrm{su}_{11}$-lum-dilmun ${ }^{\mathrm{k1}}$-gim túg-gim ba-e-dul

84. adda-da-ni-a ur ba-[e]-ná

85. gá-rig ${ }_{7}$-ga-na uga mušen [ba-e-tuš]

86. ur mu-un-da-ab-kú me-ri-ne-šè ba-[e-ná]

87. uga ${ }^{\text {mušen }}$ mu-un-da-ab-kú an-na ba-e-e ${ }_{11}$

${ }^{20}$ Preceding $s u h$ is an illegible sign. 
PLATE II



BM 100046: obverse. 


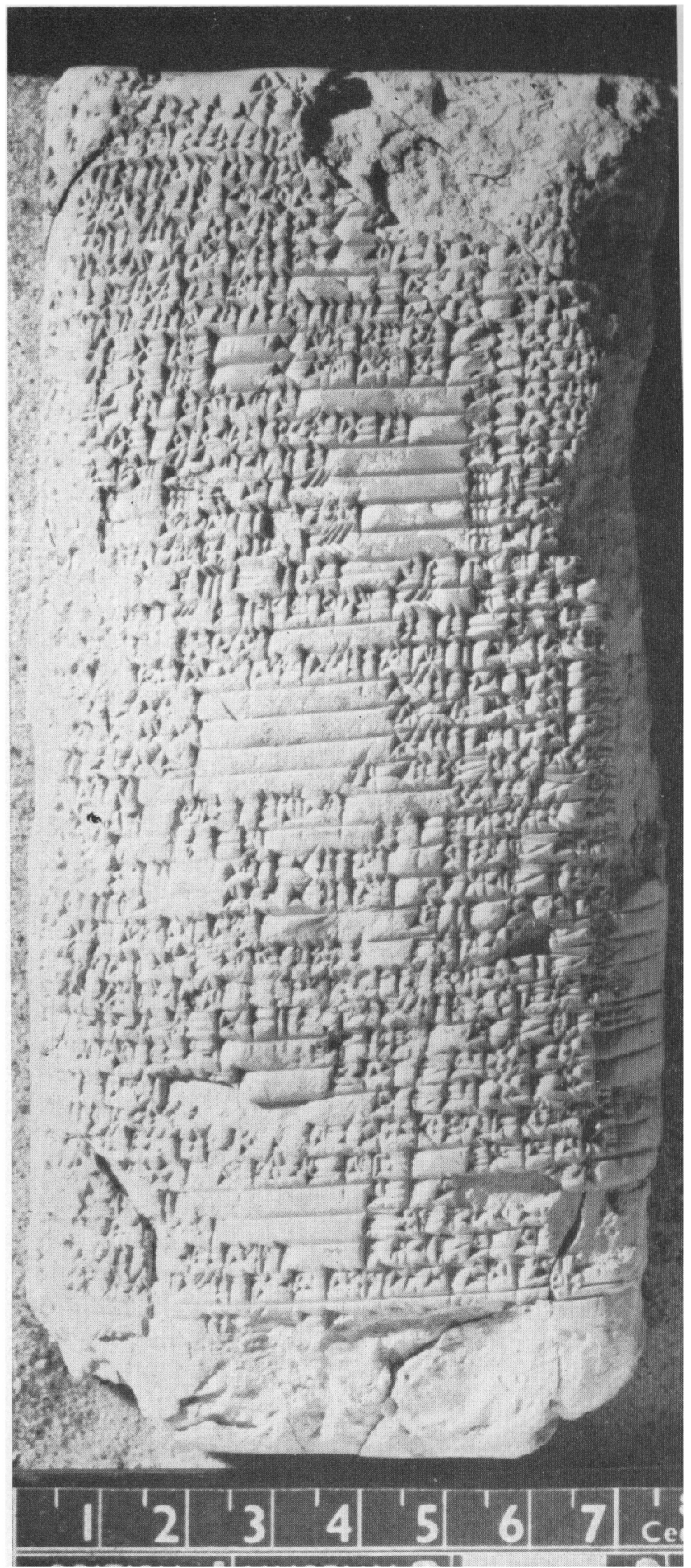

BM 100046: reverse. 


\section{Translation ${ }^{21}$}

1. [How you walk about!] How you walk about! [Why have you covered (your) head with a cloth!]

2. [You who are a shepherd], how [you walk about!]

3. [Your ewes have been seized, your lambs have been carried off,] how you walk about!

4. [Your she-goats have been seized, your kids have been carried off,] how you walk about!

5. [Your holy little donkey-mares have been seized with them,] how you walk about!

6. [Your holy churn is shat]tered, why have you covered (your) head with a cloth!

7. [Your] large kids lie prostrate in the sheep-pen,

8. Your small kids weep bitterly in the feeding-pen,

9. Your motherless lambs [utter] bitter cries at the wall's encompassing base.

10. Why does your little sister, overtaken by (their) weeping, utter supplications in their midst!

11. Your dog utters bitter cries in the desolate steppe,

12. Your spouse, the holy Inanna,

13. Weeps bitterly in her house which (having descended) from heaven, stands on the earth.

14. Your noble sister, Geštinanna,

15. By the gate of Lugalbanda,

16. By the boulevard of Ninsun,

17. Rends her rent sinews, rips out her hair,

18. Tears her torn sinews, rips out her hair,

19. Plucks out her hair like bur-rushes.

20. The lad wept at the meaning of the decreed fate,

21. Dumuzi wept at the meaning of the decreed fate:

22. "I who am a shepherd, after walking among men-how singularly I have been treated!

23. My ewes have indeed been seized, my lambs have indeed been carried off-how singularly I have been treated!

24. My she-goats have indeed been seized, my kids have indeed been carried off-how singularly I have been treated!

25. My holy little donkey-mares have indeed been seized with them-how singularly I have been [treated]!

26. My holy churn is indeed shattered-how singularly I have been [treated]!

27. My large kids are indeed [lying] prostrate in the sheep-pen,

28. My small kids are indeed weeping bitterly in the feeding-pen,

29. My motherless lambs are indeed [uttering] bitter cries at the wall's encompassing base,

30. My little sister, overtaken by (their) weeping, is indeed [uttering] supplications in their midst,

31. My dog is indeed [uttering] bitter cries in the desolate steppe,

32. My spouse, holy Inanna,

33. Is indeed weeping bitterly in her house which (having descended) from heaven, stands on the earth,

34. My noble sister, Geštinanna,

35. By the gate of Lugalbanda,

36 . By the boulevard of Ninsun,

37. Is indeed rending her sinews, is indeed ripping out her hair,

38. Is indeed rending her torn sinews, is indeed ripping out her hair,

39. Is indeed plucking out her hair like bur-rushes.

21 In the translation, two dots stand for one missing word, three dots for two missing words, four dots for three or more missing words. 
40. My foot has slid into my excavated grave, it does not let me [ascend] from it,

41. The tomb has stationed itself before me as a big door, it does not let me [ascend] from it,

42. My foot has slid into the rain-pouring cruel wind, it does not let me [ascend] from it,

43. The tempest has carried me off to the opposite shore, it does not let me ascend from it".

44. The big galla surrounded him tormented him with thirst,

45. [The little galla] surrounded him tormented him with thirst,

46. ...,

47. The galla-there being no surrounding reed hedge- - [held on to his side],

48. [They bound] his hands that had been smeared in dung (?),

49. Him who had settled himself on a lofty seat, [they seized by his thighs],

50. [They removed] the crushed cover of his holy churn.

51. On that [day] the queen did not save his life, she [gave him over] to the land of no return [as her subst]tute,

52. The spouse of Usumgalanna did not save his life she [gave him over] as her substitute,

53. Dumuzi was [held fast] by the gišbur at the ešlam,

54. He was [held fast] by the gišbur at the ešlam of(?) Ereškigal,

55. There was food there (but) it is inedible--he was [held fast] by the gišbur,

56. There was water there, (but) it was undrinkable, he was [held fast] by the gisbur,

57. At the place where Namtar dwelt he was [held fast] by the gišbur,

58. At (the place where) arts and crafts are non-existent he was [held fast] by the gišbur,

59. At (the place where) lips are covered with blood he was [held fast] by the gissbur.

60. In [those] days they were seven, they were seven,

61. [They], the sorcerers of arali, were seven,

62. [The sorcerers] of arali were seven, [they were] seven,

63. .... they were those who worked a huluppu-tree.,

64 . They were ...., they were those who worked a huluppu-tree,

65. Who knew no brother, who knew no sister, the loud cry of day and night,

66. They are those who know (how to practise) witcheraft in heaven, who [know] (how to practise) witchcraft on earth,

67. In heaven they stretch for him the gu-bad-DU,

68. They make traverse there the ... of heaven,

69. On earth they stretch for him the gu-bad-DU,

70. They cause the ... of earth to return there,

71. They ... the he-goats into his dur like a ewe,

72. The shepherd(?) in order to arouse(?) ....,

73. Brought his sheep into the gu-bad-DU-no one knew,

74. His dwelling place knew not a trespasser(?) his foot .....

75. The shepherd-man, he who practised sorcery, broke into the ground,

76. He smashed a wine-jug in the steppe, the steppe was churned like milk,

77. Swarms of birds churned it in the steppe, the steppe was churned like milk,

78. Also birds-there being no apple tree-churned it in the steppe, the steppe was churned like milk,

79. Also the young maid wrought there an ornament,

80. Also the young bride brought there bitumen,

81. The ... mes-tree brought ... there,

82. The asal-tree whose fruit had perished, [stretched] its shadow there,

83. The ... like the .., like a Dilmun-date, covered it like a garment.

84. At the side of the corpse the dog lay,

85. In his hut the raven [dwelt],

86. The dog ate by his side, [lay] at his feet,

87. The raven ate by his side, ascended to heaven. 


\section{Commentary}

Lines 1-19. The reading and meaning of e-ne ba-LU-LU in lines 1-5 are uncertain (the translation assumes the reading $b a-d i b-d i b$ for ba-LU-LU); for e-ne "how," cf. Krecher, $S K L y$ pp. 100-101. For sag túg--dul in lines 1 and 6, cf. especially sag-gá-a túg ba-an-dul, "He (Dumuzi) covered (his) head with a cloth ( $S K 26$ iv 25), which indicates that our sag is probably intended for $s a g-g a ;^{22}$ the reason for Dumuzi's covering his head with a cloth is not stated, but probably it was to avoid witnessing the calamities that had befallen him. ${ }^{23}$ The restoration of line 2 seems reasonable but is uncertain; for the restoration of lines $3-7$ of. lines $23-27$. In lines 3-5 the refrain sag túg a-na-aš $b i-i n-d u l$ is not repeated by the scribe, probably only to save labor; this may also be true for the omission of e-ne $b a-L U-L U$ in line 6 . Line 5 provides us with the rather interesting and hitherto unknown detail that Dumuzi was the possessor of small donkeymares in addition to sheep and goats. In line 6, líl-e $i$-sìg-ge, literally "it is smitten by the wind," is an idiomatic expression for "it is shattered," "it is demolished"; 24 the reason for the author's use of the present tense of the verb in this line, and not the preterite as in the preceding lines 3-5 and the following line 6 , is not clear. To judge from lines 7-9, not all Dumuzi's sheep and goats were seized and carried off, as might have been concluded from lines 3-4. Line 9 may depict the aimless wandering of the motherless lambs around the city walls. The "little sister" in line 10, is not identifiable by name. ${ }^{25}$ For Dumuzi's dog (line 11), cf. especially lines $95-97$ of "Dumuzi's Dream." In line 13, one might have expected $e^{-11}$-dè following an-ta (cf. line 200 of "Temple Hymns" and line 31 of "Gilgameš and Agga"). For the rendering -e- following nin(line 14) as "noble," cf. Falkenstein, $Z A$ 56: 90-91. In lines 17-19, the poet makes use of several rather unusual repetitions to depict Geštinanna's self-torture and especially the tearing of her hair. The Emesal, $\dot{u}$-šu-mu-búr (line 19) corresponds to the Emegir numún-bûr (line 39), corroborating Falkenstein's deduction in $M S L$ IV p. 23 that šumu(n) is the Emesal form of numun. ${ }^{26}$

Lines 20-43. For lines 20-21, cf. note 7. For line 22 cf. note 8. For dili a-na mu-un-ag, cf. lines 392 and 421 of "Enki and the World Order," where Inanna complains dili-mu-de a-na bi-ag which may be rendered "how singularly I have been treated" (literally "in my singleness how I have been treated"). In lines 37-38, which correspond to lines 17-18, note the minor variants in the initial complexes. Lines $40-43$ have no corresponding lines in the first section of the composition; they seem to depict Dumuzi's imaginary vision of his death and burial (cf. note 9). A more literal meaning of kur ki-in-dar-ra-mà in line 40 might perhaps be "in my excavated (funeral) mound". For gir--zer (line 40, also me-ri-zer in line 42), "to slide." "to slip," cf. $A H w$ sub nehelşu ${ }^{27}$ the restoration of the refrain in lines $40-43$ is uncertain, as is also its translation. In line 42, the initial complex im-hrul-šeg-gá seems to correspond grammatically to the initial complex of line 40, while me-ri-mà seems to be the Emesal of gir-mà, but on the surface there

${ }^{22} \mathrm{Cf}$. also line 103 of $a-a b-b a$ hhu-luh-ha (YNER p. 95) where the locative - $a$ is governed by $t$ i $g$-dul. On the other hand, in line 205 of "Temple Hymns" where Inanna is said to cover the head of males with a cloth, the verbal form is sag-túg-dul-lu.

${ }_{23}$ Similarly in the $a-a b-b a b u$-luh-ha line cited in the preceding note, Enlil covers his head that he might not witness the suffering of his people.

24 For other examples of líl-e--sìg cf. umuš-bi in-suh̆-àm líl-e bí-in-sìg-àm, "Its (Nippur's) reason has become confused, it has been demolished" (line 105 of the "Lamentation Over the Destruction of Nippur"); tùr-nun-e-ba-dù-a-bi lil-lu-gim ib-sig, "The stall built by the prince has been demolished" (literally, "has been smitten like by the wind"), ibid. lines 1-2; zarah-e á mu-ni-tal-tal-la líl-šè (variant lil-e) im-mi-in-sig, "The wailing that had engulfed him, he (the man's personal god) demolished" (line 127 of Jacob Klein's manuscript of "Man and His God").

${ }^{25}$ Dumuzi's nin-bàn-da is also mentioned in "Dumuzi's Dream" (line 14); for additional examples cf. Alster's comment to the line.

${ }^{28}$ For further details of. note 4 of my article "Inanna and the numun-plant," in the forthcoming Cyrus Gordon Festschrift; for the possible meaning of numún-bur, cf. CAD sub elpetu.

${ }_{27}$ Note, however, that one might have expected gir-mu rather than gir-mà if the translation is correct. 
seems to be no justification for the use of Emesal in this line; ${ }^{28}$ the rendering of lines $42-43$, which must relate in some way to Dumuzi's death vision, is quite uncertain. ${ }^{29}$

Lines 44-50. Lines 44-45 correspond in large part to lines $156=183=218$ of "Dumuzi's Dream" where the verb reads $b a-n i-i n-d u_{8}-u s^{30}$. The rendering "thirst" for $a-n i g i n(-n a)$ (literally probably "water deprivation," cf. the equation ni-gin $=N I G I N=k a-l u-u ́$ ša $A . M E \breve{S}$ in $C A D$ 8:95) was first suggested in my translation of the "Lamenatation Over the Destruction of Sumer and Ur" (ANE T' p. 611 ff.) where lines 393-395 read:

šà-gar-e uruki a-gim ba-e-si gá-la nu-un-ta-dag-ge

šà-gar-e igi-bi in-gam-me-e sa-bi im-lu-gú-dè

un-bi a-nigín-na ba-e-si zi-Hun i-ag-e

Famine filled the city like water, there is no respite from it,

Famine bends low their faces, it swells their sinews,

Its people were filled with thirst, ...

This rendering is further corroborated by lines 408-410 of the lamenatation which read:

urik1-ma gištukul-e duk-sahár-gim sag-gaz i-ag-e

lú-kar-ra-bi dùg nu-um-gá-e bàd-zag-bi im-tab

$\mathrm{ku}_{6}$-a-nigín-na-lu-ga-gim zi-bi I-tùm-tùm-mu-dè

$\mathrm{Ur}$ is shattered by the weapon like a sahar-vessel,

They who flee it cannot run fast, they were pressed tight to the side of the wall,

Like fish writhing(?) in thirst, their life is carried off. ${ }^{31}$

For the restoration of line 47, cf. the last line of the Scheil text $R A$ VIII p. $161 \mathrm{ff}$. For gi-šskur with the meaning "reed fence" (of a corral), cf. Civil apud Sladek's Dissertation "Inanna's Descent to the Nether World" p. 216-217; the rendering "surrounding" for NIGfN (following gi) seems reasonable but the complex is difficult to analyze grammatically. The restoration of the verbal form

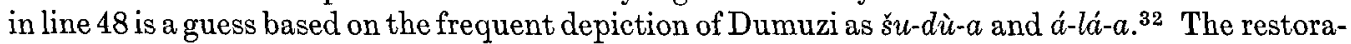
tion of line 49 is based on lines 349-350 of "Inanna's Descent to the Nether World which read":

ddumu-zi bara-mah̆-a i-im-tuš mah̆-a-DÚR-a dúr im-mi-gar

galla-e-ne haš

Dumuzi seated himself on a lofty dais, settled himself on a lofty seat(?),

The galla seized him by his thighs. ${ }^{33}$

${ }^{28}$ In this line and the line following, Dumuzi seems to have envisioned vicious winds and storms accompanying his death; for similar motifs in connection with Dumuzi's death, cf. lines $12 \mathrm{ff}$. of the "Dumuzi and the galla" passage cited in the forthcoming study mentioned in note 3 (cf. also the Flood motif involving Inanna and Dumuzi in lines $35 \mathrm{ff}$. of "Inanna and the numun-plant," the composition mentioned in note 25 ).

${ }^{29}$ For bal-ri, cf. $C A D$ sub ebertan and ebertu(A), and the rather obscure bal-a-ri of the Samsuiluna text published by Gertrud Farber-Flügge in the Kramer Festschrift p. $177 \mathrm{ff}$.

${ }^{30}$ Note that $d u_{8}$ is also omitted in several of the variants cited in "Dumuzi's Dream" to lines 156 , 182 , and 218 .

${ }^{31}$ Note that a-nigin can be read a-nimin and is probably therefore but a variant form of enmen, immen "thirst," (cf. CAD sub sumu). Note further that in $S K 25$ viii (cf. Krecher, $S K L y$ p. 216) lines $45-46$, nigin (without the preceding $a$ ) is to be rendered "thirst," since it is juxtaposed to $u_{4}-s \bar{u}$ " "hunger" (this was first suggested by Mark Cohen in his forthcoming monograph on the iršemma, in his comment to lines 22-23 of the Nergal iršemma, $C T 15$ plate 14). Moreover a comparison of $S K 25$ viii 46 with its duplicate $C T 15$ plate 7 line 24, shows that the word for "thirst" can also appear in the form anaman (written a-nag-an) since it is juxtaposed to $u-k u$, a variant of $u_{4}-s^{\prime} u$; the rendering of $C T 15$ plate 7 lines 23-24 is therefore: "I (Inanna) am one whose fledglings of the nest are hungry, I am one whose young of the stall are thirsty." For additional proof that a-nigin means "thirst," "water deprivation," cf. $B E$ XXX No. 2 lines $30-31$ that read:

ù-šub-ba-za ù-zi-ga-za sìr-re-eš na-ri-bé

guruš a-nigín-na-za šul(?) a-tar-ra-za sir-re-eš na-ri-bé

Of your food that has been abandoned, of your food that has been carried off, she (your mother) will utter a chant for you,

Lad, of your water that has been with-held; young man, of your water that has been cut off, she will utter a chant for you.

Finally it is to be noted that the a-nigin of line 71 of the Ninkasi hymn (Civil, Oppenheim Festschrift p. $61 \mathrm{ff}$.) is also probably best rendered as "thirst," though the context is not too clear.

${ }^{32}$ Cf. Dumuzi's Dream p. 112-113.

${ }^{33}$ Note, however, that there is no $d u$ r immediately preceding ba-gar-ra-àm in our text, and that the grammatical structure of mah-a-dúr-a is rather uncertain. 
For line 50, cf. lines 32 and 54 of "Dumuzi's Dream", and Alster's commentary on p. 92.

Lines 51-59. For the restoration of the second half of lines 51-52, cf. especially $U E T$ No. 11

line 27 which reads:

mà-e ki-gar-ra-bi-šè kur šè ba-ab-si-mu-dè

Me she gives over to the kur as its substitute. ${ }^{34}$

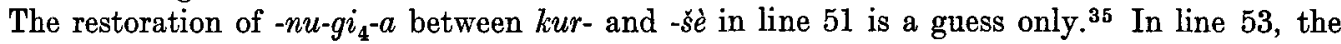
-de following ${ }^{d} d u m u-z i$ - is grammatically unjustified; the restoration of the verbal form in this line and the following six lines is reasonably assured. ${ }^{36}$ The rendering of line 54 assumes that the $-s ̌ e$ following ès-lam is a scribal error. For nam-galam as the Sumerian equivalent of the English "arts and crafts," cf. especially lines 66-67 of "Enki and the World Order" which read:

é-kur-re é-den-líl-lá-ta

abzu-eridu ${ }^{\mathrm{ki}}$-mu-šè nam-galam mu-túm

From the Ekur, the house of Enlil,

I brought the arts and crafts to my abzu, Eridu.

Lines 60-74. This passage, which must be related in some way to the following and concluding section of the composition that begins with a sorcery-practising shepherd digging a grave in the steppe, is incomprehensible in large part. Lines 60-62 introduce seven sorcerers of arali in a style characteristic of Sumerian narrative poetry. ${ }^{37}$ The remainder of the passage is largely obscure and the reading and rendering of many of the complexes are difficult and dubious. ${ }^{38}$

Lines 75-87. In line 75, the complex ki-a-dar (rather than ki-dar is rather unexpected; the -e- of ba-e-dar in this line (and in the relevant verbal forms in lines 76 and 84-87) is an as yet inexplicable pleonastic orthography, and is not semantically significant. The rendering of the verbal root hur in lines 75-78 is uncertain, as are also the real meaning and implication of the passage (note that the "it" in lines 77-78 may refer to the smashed wine-jug, and that line 78 may be no more than an amplification of line 77). The nuance intended by the initial $\dot{u}$ in lines 78-80 is not too clear, the rendering "also" is not much of a help for its clarification. For suh-kès, (line 79) of. Adele Berlin's forthcoming Enmerkar and Ensuhkešdanna (comment to line 23); the significance of the making of an ornament in the steppe (assuming the rendering is correct) is not clear (nor is that of the bringing of pitch in line 80). In line 81, it is assumed that the $g u$ (or gú-bala) qualifies the ${ }^{g i}{ }^{i} m e s$, and that this complex is the subject of the verb (hence the absence of the subject element -e following ${ }^{\text {gl }}{ }^{3} \mathrm{mes}$ ). ${ }^{39}$ For the asal-tree (line 82), cf. CAD sub sarbatu, and note that to judge from our text it is a fruit tree. In line 83 there seem to be too many gim-complexes, which makes the meaning of the line as a whole uncertain. For lines 84-85, cf. CT 15 plate 18 lines 38-39 and Krecher, SK Ly pp. 153-154. The rendering of the -dain $m u$-un-da-ab-kú (lines 86-87) as "by his side," is far from certain. ${ }^{40}$

${ }^{34}$ The -bi following $k i$-gar-ra- is rather difficult, the rendering assumes that it refers to kur, that is, the substitute has been given over to the kur as its possession; it is not impossible, however, that the $-b i$ is an error for $-n i$.

35 The rendering of lines $51-52$ is rather uncertain because of the ambiguity of the complex KI.BI.GAR.NA which may be read gisbun (or subun)-na, although this hardly fits the context; the matter is complicated, however, by the fact that in the phonetically written passage $S K 44$ rev. $2-7$, following the statements "Inanna was not alive" and "the spouse of holy Inanna was not alive," there follows a word $n i-e \breve{s}-b u-n a$ which is probably a phonetic writing for gišbun.

${ }^{30}$ Cf. especially Heimpel, Tierbilder p. $224 \mathrm{ff}$.

${ }^{37} \mathrm{Cf} . S E M 20 \mathrm{obv} .6 \mathrm{ff}$. and "Gilgames and the Land of the Living" (B) line $31 \mathrm{ff}$. Note that the restoration of the initial complexes of lines 61-62 is a surmise only, and that the nuance intended by the $h \hat{e}-$ in imin hé-na-me-eš (lines 60-61) and in what seems to be no more than a variant writing imin-na héen-na-me-eš (line 62), is uncertain.

${ }^{38}$ Especially troublesome are the $-a g$ complexes of lines $63-64$; the seeming lack of a verb in line 65 and the uncertainty of this line's connection with what precedes and follows; the meaning of $g u-b a d-D U$ in lines $67,69,73$; the identity of the individual to whom the -na- of the verbs in lines 67 and 69 refers (presumably it is Dumuzi); the meaning of dúr in line 71 ; the uncertainty of the reading and rendering of virtually all the complexes in line 72; the meaning of bala in line 74.

${ }^{39}$ Or perhaps ${ }^{0 i \delta^{\prime}}$ mes is followed by a relative clause just as ${ }^{g i s_{\text {asal }}}$ in the following line.

${ }^{40}$ In line 86 the missing subject element after $u r$ may be due to the fact that $u r$ is the subject of the intransitive be-e-ná as well as of the syntactically less important transitive $m u-u n-d a-a b-k u$. 